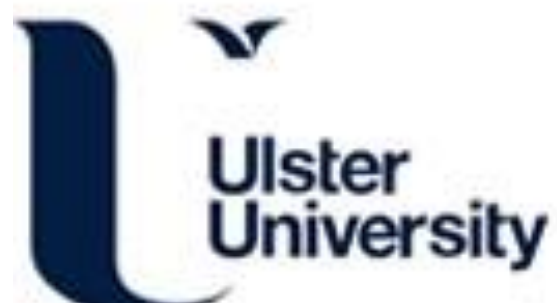

\section{Electronic structure and bonding properties of Si-doped hydrogenated amorphous carbon films}

Ray, SC., Bao, CW., Tsai, HM., Chiou, JW., Jan, JC., Kumar, KPK., Pong, WF., Tsai, MH., Wang, WJ., Hsu, CJ., Okpalugo, TIT., Papakonstantinou, P., \& McLaughlin, JAD. (2004). Electronic structure and bonding properties of Si-doped hydrogenated amorphous carbon films. Applied Physics Letters, 85(18), $4022-4024$. https://doi.org/10.1063/1.1812594

Link to publication record in Ulster University Research Portal

\section{Published in:}

Applied Physics Letters

Publication Status:

Published online: 03/11/2004

DOI:

10.1063/1.1812594

\section{Document Version}

Publisher's PDF, also known as Version of record

\section{General rights}

Copyright for the publications made accessible via Ulster University's Research Portal is retained by the author(s) and / or other copyright owners and it is a condition of accessing these publications that users recognise and abide by the legal requirements associated with these rights.

\section{Take down policy}

The Research Portal is Ulster University's institutional repository that provides access to Ulster's research outputs. Every effort has been made to ensure that content in the Research Portal does not infringe any person's rights, or applicable UK laws. If you discover content in the Research Portal that you believe breaches copyright or violates any law, please contact pure-support@ulster.ac.uk. 


\title{
Electronic structure and bonding properties of Si-doped hydrogenated amorphous carbon films
}

\author{
S. C. Ray, C. W. Bao, H. M. Tsai, J. W. Chiou, J. C. Jan, \\ K. P. Krishna Kumar, and W. F. Pong ${ }^{\text {a) }}$ \\ Department of Physics, Tamkang University, Tamsui, Taiwan 251, Republic of China \\ M.-H. Tsai \\ Department of Physics, National Sun Yat-Sen University, Kaohsiung, Taiwan 804, Republic of China \\ W.-J. Wang and C.-J. Hsu \\ Department of Chemistry, Tamkang University, Tamsui, Taiwan 251, Republic of China
}

T. I. T. Okpalugo, P. Papakonstantinou, and J. A. McLaughlin

NIBEC, School of Electrical and Mechanical Engineering, University of Ulster, County Antrim BT370QB, Northern Ireland, United Kingdom

(Received 14 May 2004; accepted 2 September 2004)

\begin{abstract}
This work investigates the $\mathrm{C} K$-edge $\mathrm{x}$-ray absorption near-edge structure (XANES), valence-band photoelectron spectroscopy (PES), and Fourier transform infrared (FTIR) spectra of Si-doped hydrogenated amorphous carbon films. The $\mathrm{C} K$-edge XANES and valence-band PES spectra indicate that the $s p^{2} / s p^{3}$ population ratio decreases as the amount of tetramethylsilane vapor precursor increases during deposition, which suggest that Si doping\% enhances $s p^{3}$ and reduces $s p^{2}$-bonding configurations. FTIR spectra show the formation of a polymeric $s p^{3} \mathrm{C}-\mathrm{H}_{n}$ structure and $\mathrm{Si}-\mathrm{H}_{n}$ bonds, which causes the Young's modulus and hardness of the films to decrease with the increase of the Si content. (C) 2004 American Institute of Physics. [DOI: 10.1063/1.1812594]
\end{abstract}

Diamond-like carbon (DLC) is a unique material useful as a protective overcoating on magnetic disk drives because it has a unique combination of high hardness, low friction and wear, electrical insulation, and chemical inertness. ${ }^{1}$ However, several problems have arisen in this usage. DLC as hydrogenated amorphous carbon $(a-\mathrm{C}: \mathrm{H})$ has limited thermal stability, poor adhesion to some substrates such as steels, high internal stress, and a friction coefficient that strongly depends on the relative humidity of the environment. Si-doped DLC films have been found to stabilize $s p^{3}$ bonding, reduce stress and dependence of the friction coefficient on relative humidity, improve adhesion to metal substrates, and increase thermal stability and band gap. ${ }^{2}$ A range of hydrogenated amorphous carbon-containing silicon $(a-\mathrm{C}: \mathrm{H}: \mathrm{Si})$ films were deposited on $\mathrm{Si}(100)$ substrate by plasma-enhanced chemical vapor deposition (PECVD) method using tetramethylsilane $\left[\mathrm{Si}\left(\mathrm{CH}_{3}\right)_{4}, \mathrm{TMS}\right]$ vapor as a $\mathrm{Si}$ precursor. Their various structural and mechanical properties were investigated previously. ${ }^{2}$ This work focuses on the role and effect of the incorporation of $\mathrm{Si}$ on the electronic structure and bonding properties of $a-\mathrm{C}: \mathrm{H}: \mathrm{Si}$ thin films.

$\mathrm{C} K$-edge x-ray absorption near-edge structure (XANES) and valence-band photoelectron spectroscopy (PES) measurements of $a-\mathrm{C}: \mathrm{H}$ and $a-\mathrm{C}: \mathrm{H}: \mathrm{Si}$ films were performed at the National Synchrotron Radiation Research Center (NSRRC), Hsinchu, Taiwan. Fourier transform of the infrared (FTIR) spectra were obtained using the FTIR spectrophotometer for wavelengths in the range between 400 and $3800 \mathrm{~cm}^{-1}$. The films used in this work were prepared by the PECVD method on the $\mathrm{Si}(100)$ substrate at a bias voltage of $400 \mathrm{~V}$ and at different deposition time. The film compositions, deposition time, thickness, and mechanical properties

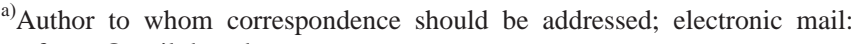
wfpong@mail.tku.edu.tw
}

of these films are presented in Table I and described elsewhere. $^{2}$

Figure 1 displays the normalized $\mathrm{C} K$-edge XANES spectra of $a-\mathrm{C}: \mathrm{H}$ and $\left(\mathrm{B}_{0}\right)$ and $a-C: \mathrm{H}: \mathrm{Si}\left(\mathrm{B}_{1}-\mathrm{B}_{4}\right)$ films and the reference graphite. The graphite spectrum shows that $\pi^{*}$ and $\sigma^{*}$ bands are located at $\sim 285.5$ and $291.7 \mathrm{eV}$, respectively, while the $\pi^{*}$ and $\sigma^{*}$ bands in the $a-\mathrm{C}: \mathrm{H}$ and $a-C: \mathrm{H}: \mathrm{Si}$ spectra are located at $\sim 286.1$ and $293.0 \mathrm{eV}$. The $\pi^{*}$ feature is typical of the $\mathrm{C}=\mathrm{C}\left(s p^{2}\right)$ bond and the $\sigma^{*}$ feature is typical of the tetrahedral $\mathrm{C}-\mathrm{C}\left(s p^{3}\right)$ bond. The $286.1 \mathrm{eV} \pi^{*}$ feature in the $a-\mathrm{C}: \mathrm{H}$ and $a-\mathrm{C}: \mathrm{H}: \mathrm{Si}$ spectra is higher than that of the $\mathrm{C}=\mathrm{C}$ bond $(\sim 285.5 \mathrm{eV}$ : graphite $)$ but below that of the $\mathrm{C}-\mathrm{H}$ bond $(\sim 288 \mathrm{eV}$ : generally observed in $\alpha-\mathrm{C}: \mathrm{H}$ film $\left.{ }^{3,4}\right)$ in the XANES spectra of all of the $a$-C:H:Si samples. There is an energy sift of $\sim 0.6 \mathrm{eV}$. The intensities in all $a-\mathrm{C}: \mathrm{H}: \mathrm{Si}$ spectra were also observed to be higher in the range $\sim 288-295 \mathrm{eV}$ but lower in the range $\sim 295-308 \mathrm{eV}$ than those in the $a-\mathrm{C}: \mathrm{H}$ spectrum. This effect can be clearly seen in the difference spectra between $a-\mathrm{C}: \mathrm{H}: \mathrm{Si}\left(\mathrm{B}_{1}-\mathrm{B}_{4}\right)$ and $a-\mathrm{C}: \mathrm{H}\left(\mathrm{B}_{0}\right)$ presented in the inset of Fig. 1. The intensity increases gradually in the region $288-295 \mathrm{eV}$ and decreases slowly in the region $295-308 \mathrm{eV}$ as Si doping increases. This trend can be interpreted as due to the formation of the $\mathrm{C}-\mathrm{H}_{n}$ and $\mathrm{Si}-\mathrm{H}_{n}$ bonds to be described later in the discussion of the FTIR measurements. None of the prominent $\mathrm{Si}-\mathrm{C}$ peaks in the XANES spectra, as observed by García et al. ${ }^{5}$ for diamond nuclei on silicon and Tsai et al. ${ }^{6}$ for $\mathrm{SiC}$, were observed in this study.

Figure 2 presents the valence-band PES spectra of $a-\mathrm{C}: \mathrm{H}$ and $a-\mathrm{C}: \mathrm{H}:$ Si films obtained using an incident photon energy of $60 \mathrm{eV}$. The spectrum of the $a-\mathrm{C}: \mathrm{H}$ film is dominated by two overlapping broad peaks centered at around $3 \mathrm{eV}(\mathbf{I})$ and $7 \mathrm{eV}(\mathbf{I I})$, which correspond to $p_{\pi}$ and $p_{\sigma}$ bands, respectively. ${ }^{7}$ The peak positions in the spectra of $a-\mathrm{C}: \mathrm{H}: \mathrm{Si}$ films shift gradually from $\sim 3.4$ to $4.2 \mathrm{eV}$ for the 
TABLE I. The TMS flow rate, deposition time, film composition, thickness, and Young's modulus of $a-\mathrm{C}: \mathrm{H}$ and $a-\mathrm{C}: \mathrm{H}: \mathrm{Si}$ films.

\begin{tabular}{|c|c|c|c|c|c|c|c|}
\hline \multirow[t]{2}{*}{ Sample No. } & \multirow{2}{*}{$\begin{array}{l}\text { TMS flow } \\
\text { (sccm) }\end{array}$} & \multirow{2}{*}{$\begin{array}{c}\text { Dep time } \\
\text { (s) }\end{array}$} & \multirow{2}{*}{$\frac{\text { Composition (at.\%) }}{\mathrm{C}}$} & \multirow[b]{2}{*}{$\mathrm{Si}$} & \multirow[b]{2}{*}{$\mathrm{O}$} & \multirow{2}{*}{$\begin{array}{l}\text { Thickness } \\
\text { (nm) }\end{array}$} & \multirow{2}{*}{$\begin{array}{c}\text { Young's Modulus } \\
E(\mathrm{GPa})\end{array}$} \\
\hline & & & & & & & \\
\hline$a-\mathrm{C}: \mathrm{H}\left(\mathrm{B}_{0}\right)$ & 0 & 480 & 84.2 & 0.30 & 15.5 & 178 & $187.0 \pm 0.6$ \\
\hline$a-\mathrm{C}: \mathrm{H}: \mathrm{Si}\left(\mathrm{B}_{1}\right)$ & 05 & 300 & 69.4 & 10.2 & 20.4 & 172 & $156.7 \pm 2.3$ \\
\hline$a-\mathrm{C}: \mathrm{H}: \mathrm{Si}\left(\mathrm{B}_{2}\right)$ & 10 & 180 & 68.4 & 18.4 & 13.2 & 184 & $148.5 \pm 2.8$ \\
\hline$a-\mathrm{C}: \mathrm{H}: \mathrm{Si}\left(\mathrm{B}_{3}\right)$ & 15 & 135 & 62.0 & 14.5 & 23.5 & 166 & $142.8 \pm 3.4$ \\
\hline$a-\mathrm{C}: \mathrm{H}: \mathrm{Si}\left(\mathrm{B}_{4}\right)$ & 20 & 90 & 63.2 & 19.7 & 17.1 & 176 & $141.8 \pm 3.4$ \\
\hline
\end{tabular}

$p_{\pi}$ band and from $\sim 7.2$ to $7.9 \mathrm{eV}$ for $p_{\sigma}$ band as the TMS flow rate increases. The dominant feature has a shoulder located at $10-11 \mathrm{eV}($ III) and a broad feature at about $17 \mathrm{eV}$ (IV) in the spectra of $a-\mathrm{C}: \mathrm{H}$ and $a-\mathrm{C}: \mathrm{H}: \mathrm{Si}$ films is also observed. The spectra can be deconvoluted with four Gaussian peaks as shown in inset (a) of Fig. 2 using the spectrum of the $\mathrm{B}_{4}$ sample as an example. The shift of the dominant feature and the change in intensity can be clearly seen in inset (b) of Fig. 2, in which a common base line (dashed line shown in Fig. 2) was subtracted from all of the spectra. The intensities of peaks II and I increase and decrease, respectively, as the $\mathrm{Si}$ concentration increases, corresponding to the enhancement and reduction of $s p^{3}$ and $s p^{2}$ states, respectively. This finding implies the formation of $s p^{3}$-rich $a-\mathrm{C}: \mathrm{H}: \mathrm{Si}$ films with $\mathrm{Si}$ incorporation. The shoulder III (at $\sim 11 \mathrm{eV}$ ) is presumably associated with the $\mathrm{C}-\mathrm{H}_{n}$ bonds. Peak IV was argued by Reinke $e t$ al. to be due to the surface plasmon of the $s p^{2}$ states. $^{7}$

The FTIR spectra normalized with the thickness shown in Fig. 3 contain absorption peaks of various vibration modes in the $400-3800 \mathrm{~cm}^{-1}$ range for the films deposited at different TMS flow rates and the reference Si substrate. The first sharp peak at $612 \mathrm{~cm}^{-1}$ and the features in the $700-1000 \mathrm{~cm}^{-1}$ range were assigned to the $\mathrm{Si}-\mathrm{C}(\mathrm{s})$ stretching mode ${ }^{8}$ and $\mathrm{Si}-\mathrm{C}(s), \mathrm{Si}-\mathrm{H}_{n}(s)$, and $\mathrm{Si}-\mathrm{CH}_{n}$ wagging modes, ${ }^{9-11}$ respectively. The peak at $1100 \mathrm{~cm}^{-1}$ was assigned to the $\mathrm{Si}-\mathrm{O}$ stretching mode ${ }^{12}$ of the $\mathrm{Si}-\mathrm{O}$ bonds due to oxidation of $\mathrm{Si}$ in the film and silicon substrate. The spec-

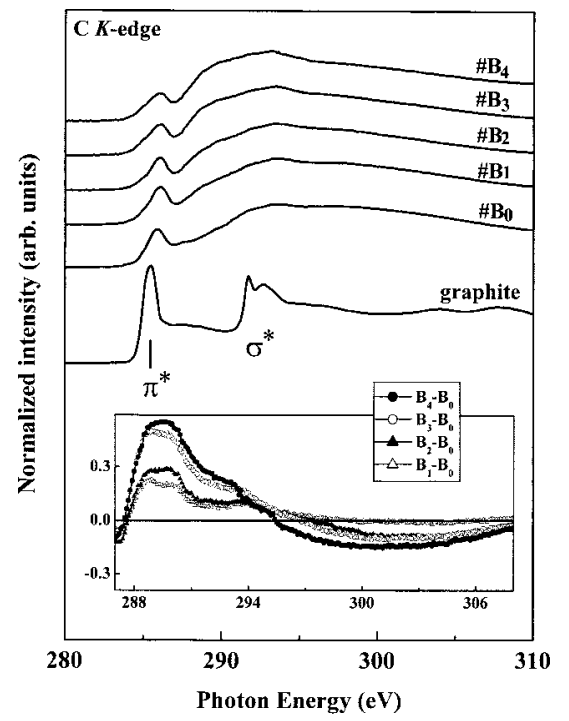

FIG. 1. Normalized C $K$-edge absorption spectra of the $a-\mathrm{C}: \mathrm{H}: \mathrm{Si}$ films, $a-\mathrm{C}: \mathrm{H}$ film and the reference graphite film. The inset presents the difference curves between the spectra of the $a-\mathrm{C}: \mathrm{H}: \mathrm{Si}$ and $a-\mathrm{C}: \mathrm{H}$ films.

Downloaded 15 Oct 2009 to 193.61 .144 .8 . Redistribution subject trum of the Si-free $a-\mathrm{C}: \mathrm{H}$ film shows the presence of $\mathrm{C}-\mathrm{H}_{n}(s)$ stretching modes $\left(2675-3250 \mathrm{~cm}^{-1}\right),{ }^{9-12}$ whereas the spectra of Si-containing $a-\mathrm{C}: \mathrm{H}: \mathrm{Si}$ films show the presence of not only $\mathrm{C}-\mathrm{H}_{n}(s)$ stretching modes $\left(2675-3250 \mathrm{~cm}^{-1}\right)$ but also $\mathrm{Si}-\mathrm{H}_{n}(s)\left(2025-2250 \mathrm{~cm}^{-1}\right)$ modes. ${ }^{9-11}$ The peaks in the $1240-1580 \mathrm{~cm}^{-1}$ range for all films were attributed to the mixing of $\mathrm{Si}-\mathrm{CH}_{3}$ wagging, $\mathrm{C}-\mathrm{H}_{n}(b)$ bending, $s p^{3} \mathrm{C}-\mathrm{C}(s)$, and $s p^{2} \mathrm{C}=\mathrm{C}(s)$ modes. The weak feature at $1700 \mathrm{~cm}^{-1}$ attributable to $\mathrm{OH}$ may be caused by surface contamination. The doublet peak (centered at $\sim 2350 \mathrm{~cm}^{-1}$ ) between $\mathrm{Si}-\mathrm{H}_{n}$ and $\mathrm{C}-\mathrm{H}_{n}$ peaks is associated with environmental $\mathrm{CO}_{2}$. The intensities of the $\mathrm{C}-\mathrm{H}_{n}(s)\left(2025-2250 \mathrm{~cm}^{-1}\right) \quad$ and $\mathrm{Si}-\mathrm{H}_{n}(s)(2675$ $-3250 \mathrm{~cm}^{-1}$ ) modes change markedly with the TMS flow rate as clearly shown in the inset of Fig. 3, whereas the intensities of all other peaks do not change significantly. The presence of $\mathrm{Si}-\mathrm{H}_{n}$ bonds in the FTIR spectra suggests that $\mathrm{Si}$ dopants are coordinated with hydrogen atoms in the film structure.

The integrated intensities of the FTIR absorption peaks attributable to $\mathrm{C}-\mathrm{H}_{n}(s)\left(2025-2250 \mathrm{~cm}^{-1}\right)$ and $\mathrm{Si}-\mathrm{H}_{n}(s)\left(2675-3250 \mathrm{~cm}^{-1}\right)$ stretching vibrations, respectively, are calculated and plotted in Fig. 4(a) as a function of the TMS flow rate to elucidate the effect of $\mathrm{Si}$ incorporating on the chemical bonding. Figure 4(a) demonstrates that the integrated intensities of both $\mathrm{C}-\mathrm{H}_{n}(s)$ and $\mathrm{Si}-\mathrm{H}_{n}(s)$ modes increase with the increase of the TMS flow rate, which suggests the formation of a polymeric $s p^{3} \mathrm{C}-\mathrm{H}_{n}$ structure and

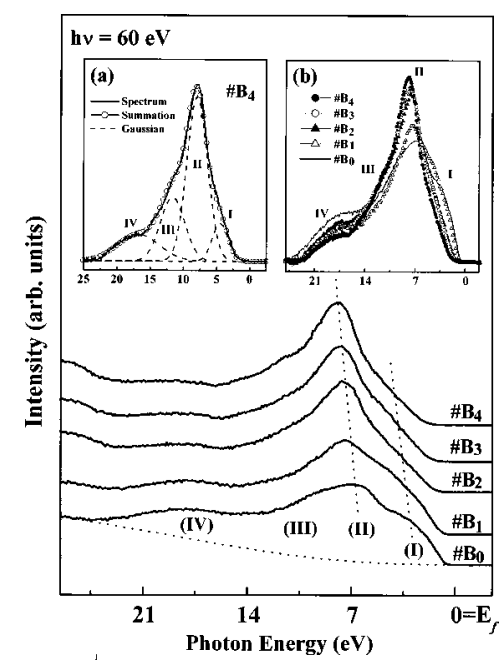

FIG. 2. Valence-band PES spectra of $a-\mathrm{C}: \mathrm{H}: \mathrm{Si}$ (at various TMS flow rates) and $a-\mathrm{C}: \mathrm{H}$. The inset (a) was obtained by deconvoluting the spectra of $a-\mathrm{C}: \mathrm{H}: \mathrm{Si}\left(\mathrm{B}_{4}\right)$ with four Gaussian peaks. The inset (b) plots the spectra of all $a-\mathrm{C}: \mathrm{H}: \mathrm{Si}$ and $a-\mathrm{C}: \mathrm{H}$ films after the base-line has been subtracted. 


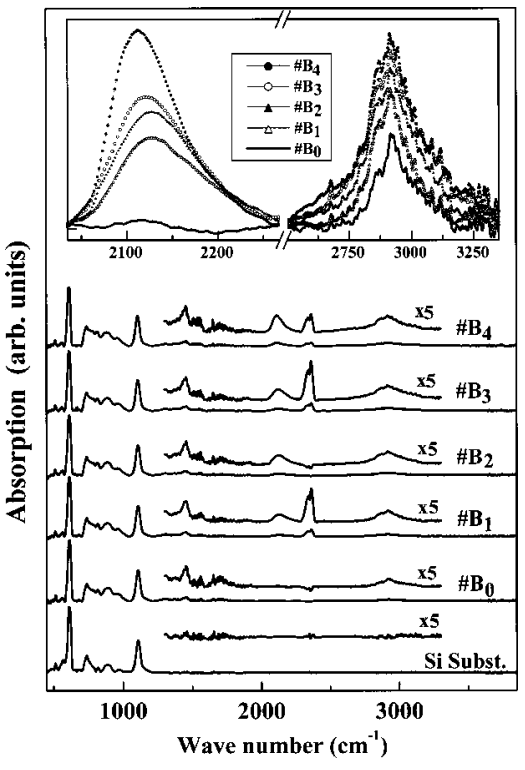

FIG. 3. Normalized FTIR spectra of films deposited with various TMS flow rates in the $400-3800 \mathrm{~cm}^{-1}$ range, in which the part in the $1200-3300 \mathrm{~cm}^{-1}$ range has been magnified five times for clarity. The inset shows the magnified $\mathrm{C}-\mathrm{H}_{n}(s)$ and $\mathrm{Si}-\mathrm{H}_{n}(s)$ modes.

$\mathrm{Si}-\mathrm{H}_{n}$ bonding in $a-\mathrm{C}: \mathrm{H}: \mathrm{Si}$ films. Figure 4(b) compares Young's modulus $(E)$ presented in Table I and the $s p^{2} / s p^{3}$ ratio obtained from C $K$-edge XANES $\left(\pi^{*} / \sigma^{*}\right)$ and valenceband PES $(\pi / \sigma)$ measurements to illustrate the effect of $\mathrm{Si}$ doping on $a-\mathrm{C}: \mathrm{H}$ films. The $s p^{2}$ and $s p^{3}$-bonded carbon contents of each sample were estimated from the relative heights of the $\pi^{*}(286.1 \pm 0.1 \mathrm{eV})$ and $\sigma^{*}(293.0 \pm 0.1 \mathrm{eV})$ features (Fig. 1) and the $\pi$ and $\sigma$ features obtained by fitting to peaks I and II in the PES spectra [Fig. 2(b)], respectively. The $s p^{2} / s p^{3}$ ratio declines as the TMS flow rate increases and/or Si doping increases.

Figure 4(b) shows that the Young's modulus increases when the $I_{s p 2} / I_{s p 3}$ ratio increases. This trend is in contrast to the usual observation that the increase of the Young's modulus is accompanied by a decrease of the $I_{s p 2} / I_{s p 3}$ ratio in carbon-related materials, which concerns the exchange be-

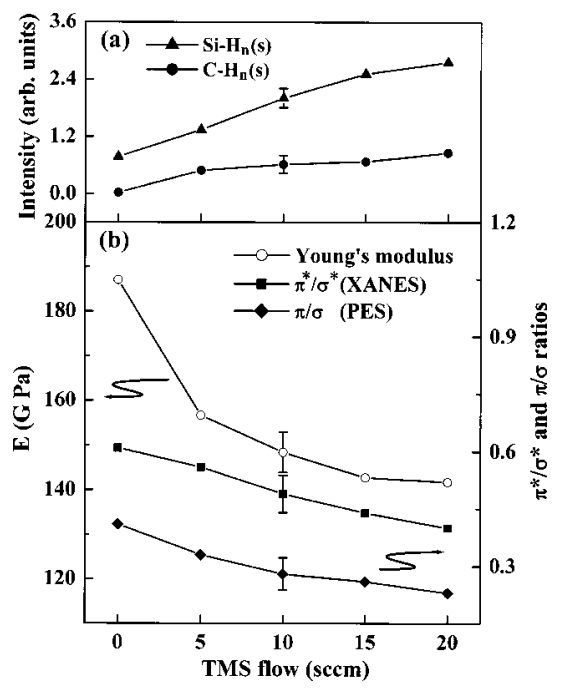

FIG. 4. (a) Integrated intensities of the $\mathrm{C}-\mathrm{H}_{n}(\mathrm{~s})$ and $\mathrm{Si}-\mathrm{H}_{n}(s)$ modes obtained from FTIR spectra. (b) The $\pi^{*} / \sigma^{*}$ ratio (from $\mathrm{C} K$-edge XANES spectra), $\pi / \sigma$ ratio (from valence-band PES spectra), and Young's modulus as functions of the TMS flow rate for all films. tween graphite-like $s p^{2}$ bonding and diamond-like $s p^{3} \mathrm{C}-\mathrm{C}$ bonding. In the present case one needs to consider the effect of hydrogen and the increase in the number of $\mathrm{C}-\mathrm{H}_{n}$ and $\mathrm{Si}-\mathrm{H}_{n}$ bonds. The $a-\mathrm{C}: \mathrm{H}: \mathrm{Si}$ films normally contain dangling bonds saturated with hydrogen, which are relaxed so that the Young's modulus and the hardness decreases as the number of $\mathrm{C}-\mathrm{H}_{n}$ and $\mathrm{Si}-\mathrm{H}_{n}$ bonds increases. Figure 4(a) shows that in Si-containing $a-\mathrm{C}: \mathrm{H}: \mathrm{Si}$ films the number of $\mathrm{Si}-\mathrm{H}_{n}$ bonds increase with the TMS flow rate, i.e., the silicon content. Therefore, the incorporation of $\mathrm{Si}$ reduces Young's modulus and hardness. In other words, the increase of the number of $\mathrm{Si}-\mathrm{H}_{n}$ bonds relaxes the three-dimensional rigid network of $a-\mathrm{C}: \mathrm{H}: \mathrm{Si}$ films. The high hydrogen concentration in the TMS precursor used to deposit the film promotes the polymeric $s p^{3} \mathrm{C}-\mathrm{H}_{n}$ bonding formation, which alters the bonding constraints of $s p^{3}$-bonded carbon and reduces the stress, hardness, and Young's modulus of the film. ${ }^{13}$ Incorporating TMS also increases the numbers of $\mathrm{C}-\mathrm{H}_{n}$ and $\mathrm{Si}-\mathrm{H}_{n}$ bonds as mentioned earlier and bonds that are weaker than $\mathrm{C}-\mathrm{C}$ bonds, so that the structural integrity of the films is weakened. [The bond energies of $\mathrm{Si}-\mathrm{H}(\leqslant 3.10 \mathrm{eV})^{14}$ and $\mathrm{C}-\mathrm{H}(3.51 \mathrm{eV})^{14}$ smaller than $\mathrm{C}-\mathrm{C}(3.70 \mathrm{eV}) .{ }^{15}$ ] The formation of $\mathrm{Si}-\mathrm{C}$ bonds (bond energy $\leqslant 3.10 \mathrm{eV})^{15}$ in the interlayer between the film and substrate may also affect the hardness of the substrate. The increase of the density of voids, as noted by Baia et al. in hydrogen effusion experiments, with the increase of Si doping in $a-\mathrm{C}: \mathrm{H}: \mathrm{Si}$ films influences the connectivity and hardness of the network. ${ }^{16}$

This work was supported by the National Science Council of the ROC under Contract No. NSC 92-2112-M-032025 .

${ }^{1}$ P. R. Goglia, J. Berkowitz, J. Hoehn, A. Xidis, and L. Stover, Diamond Relat. Mater. 10, 271 (2001).

${ }^{2}$ P. Papakonstantinou, J. F. Zhao, P. Lemoine, E. T. McAdams, and J. A. McLaughlin, Diamond Relat. Mater. 11, 1074 (2002).

${ }^{3}$ J. Nithianandam, J. C. Rife, and H. Windischmann, Appl. Phys. Lett. 60, 135 (1992).

${ }^{4}$ A. Hoffman, G. Comtet, L. Hellner, G. Dujardin, and M. Petravic, Appl. Phys. Lett. 73, 1152 (1998).

${ }^{5}$ M. M. Gracía, I. Jiménez, O. Sánchez, C. Gómez-Aleixandre, and L. Vázquez, Phys. Rev. B 61, 10383 (2000).

${ }^{6}$ H. M. Tsai, J. C. Jan, J. W. Chiou, W. F. Pong, M.-H. Tsai, Y. K. Chang, Y. Y. Chen, Y. W. Yang, L. J. Lai, J. J. Wu, C. T. Wu, K. H. Chen, and L. C. Chen, Appl. Phys. Lett. 79, 2393 (2001).

${ }^{7}$ P. Reinke and P. Oelhafen, J. Appl. Phys. 81, 2396 (1997); P. Reinke, P. Oelhafen, H. Feldermann, C. Ronning, and H. Hofsäss, J. Appl. Phys. 88, 5597 (2000).

${ }^{8}$ S. Ghosh, P. Bhattacharya, and D. N. Bose, Appl. Phys. Lett. 68, 2979 (1996).

${ }^{9}$ K. Mui, D. K. Basa, F. W. Smith, and R. Corderman, Phys. Rev. B 35, 8089 (1987)

${ }^{10}$ R. A. C. M. M. van Swaaij, A. J. M. Berntsen, W. G. J. H. M. van Sark, H. Herremans, J. Bezemer, and W. F. van der Weg, J. Appl. Phys. 76, 251 (1994).

${ }^{11}$ K. Chew, Rusli, S. F. Yoon, J. Ahn, V. Ligatchev, F. J. Teo, T. Osipowicz, and F. Watt, J. Appl. Phys. 92, 2937 (2002).

${ }^{12}$ M. Ban and T. Hasegawa, Surf. Coat. Technol. 162, 1 (2002).

${ }^{13}$ X. M. He, K. C. Walter, M. Natasi, S. T. Lee, and M. K. Fung, J. Vac. Sci. Technol. A 18, 2143 (2000).

${ }^{14}$ K. R. Lee, M. G. Kim, S. J. Cho, K. Y. Eun, and T. Y. Seong, Thin Solid Films 308/309, 263 (1997).

${ }^{15}$ C. S. Lee, K. R. Lee, K. Y. Eun, K. H. Yoon, and J. H. Han, Diamond Relat. Mater. 11, 198 (2002).

${ }^{16}$ A. L. Baia Neto, R. A. Santos, F. L. Freire, Jr., S. S. Camargo, Jr., R. Carius, F. Finger, and W. Beyer, Thin Solid Films 293, 206 (1997). 